Much of Dr Parkes's evidence concerned the criteria his committee had used for allocating funds to the various universities. The relatively favourable treatment for science is apparently accounted for by the "swing back to science" evident in recent applications from would-be students. Within biology, Dr Parkes said that the committee had taken the opportunity to encourage courses and departments with economic potential. Departments of social science, whose student numbers are to be cut collectively by 12 per cent in the next few years, will suffer chiefly at the "soft end", partly on the grounds that student demand is falling and partly because staff-student ratios in some of the departments concerned are too small for good research to be feasible. The grants committee had not, however, been influenced to any substantial extent by "manpower considerations".

Nor, according to Dr Parkes, had regional considerations played a part in his committee's planning except in special circumstances - the argument, for example, that the Universities of Glasgow and Strathclyde should between them be able to provide a full range of courses in higher education to satisfy the needs of students from south-west Scotland, where regional loyalties are strong.

The qualifications of students entering universities had counted in the grants committee's calculations, but Dr Parkes said last week that the committee had tried to strike a balance between institutions with high-quality entering students and those apparently able to provide less highly qualified students with good degrees and useful adult careers.

On the contentious issue of the research records of various departments, Dr Parkes rejected the criticism that too much attention had been given to the success with which departments were able to recruit grant support from the publicly funded research councils. Instead, he argued that industrially supported research usually provided university departments with a measure of overhead support, with the result that the grants committee could legitimately confine itself to the public provision of research support.

The joker in Dr Parkes's pack appears to be the quality of teaching in individual departments and universities, which was also one of his committee's criteria. Insisting that judgements of this kind must necessarily be to some extent subjective, and that little could be done to develop objective criteria based on graduation results, he will not have stilled the charge of prejudice made in the past few weeks by several universities.

Dr Parkes agreed, however, with the vice-chancellors that his committee's ignorance of the other sector of British higher education, represented principally by the 26 polytechnics, is a serious obstacle to sensible planning.

\section{US university research Industry to provide}

\section{Washington}

Increased incentives to private companies which support basic research in US universities were contained in a tax package, backed by President Reagan, which was passed by Congress on Monday this week.

The tax incentives were considerably broader than the Administration had initially proposed and unlike that part of the bill dealing with cuts in personal taxation, credits for spending on research received wide bi-partisan support.

Initially the Administration, in its tax package put to Congress in March, had concentrated on shortening the period in which research and development equipment could be written off. Both House and Senate have now passed bills under which such equipment can be fully depreciated over three years, two years less than is allowed for other capital equipment.

The protracted debate over these proposals gave individual congressmen a chance to add their own suggestions for reducing the tax burden on the private sector. One of these is the idea, originally raised by Representative Charles Vanik, that companies should receive substantial credit for money used" to support basic research in universities.

When the tax bill was passed to the House Ways and Means Committee, groups such as the Association of American Universities and the American Council on Education argued that such an addition would help offset reduced federal support for university research.

Dr Donald Kennedy, president of Stanford University, told the oversight subcommittee of the House Science and Technology Committee in June that the additional tax credits, which had been put forward in a separate bill sponsored by Congressman James Shannon, would "significantly invigorate" the relationship between industry and universities "without some of the hazards that I see in the present helter-skelter pattern of affiliation".

In the same vein Dr Paul Gray, president of Massachusetts Institute of Technology, told the Ways and Means Committee that tax credits would create an "urgently needed" increase in the flow of corporate funds for university research. At present about $\$ 210$ million - or 3.5 per cent - of university research funds is provided by the private sector, the bulk of the rest coming from federal government.

Responding to such arguments, the committee not only included a tax credit for any increased research expenditures, but confirmed that existing tax provisions affecting both gifts direct to academic institutions and to third-party tax-exempt organizations, such as foundations, would persist.

However Dr Kennedy and Dr Gray were

\section{Australasian fellowships}

The council of the Royal Society has set up a new research fellowship designed to further the United Kingdom's scientific collaboration with Australia and New Zealand. Main purpose of the fellowship is to improve access to major "facilities" such as unique features of the geological, oceanographic or biological environment, astronomical centres and nuclear physics and biotechnology laboratories.

The scheme is aimed at British and Australasian postdoctoral scientists wishing to undertake research or to learn new techniques. The fellowships last from three to twelve months, and are the result of discussions between the Royal Society, its Australian and New Zealand equivalents, the UK Science and Engineering Research Council and Australasian government departments. The Australasians have yet to find the funds for the scheme, so the Royal Society, encouraged by $£ 15,000$ from BP, has forked out $£ 50,000$ for the first year of the enterprise. Interested scientists and engineers, or their potential hosts, are invited to apply.

Philip Campbell

unable to convince Mr Donald Regan, Secretary of the Treasury, that the extra credits for support of university research should be included in the bill.

The bill was eventually defeated after a bitter fight over the timing of cuts in personal taxes on the floor of the House. But the Republican-sponsored measure which replaced it, with the support of several conservative Democrats, adopted virtually identical language in its section on tax credits for research expenditures within the private sector.

There were some differences. The House bill, for example, includes corporate expenditure for university research in the base from which the additional expenditures, which would be eligible for the tax credit, are calculated. This will substantially reduce the size of the credits over those supported by the committee. In addition, the House bill specifically excludes tax credits for the support of research in the social sciences and the humanities.

The result is that there will be a small credit for basic research as well as a provision that research equipment given to a university, provided it is less than two years old, can be counted by a company as a charitable contribution.

The major question now is whether all the proposais made in the House bill will be agreed by the Senate. At present, however, the Senate version does not include the tax break for basic support in universities. Representatives from the two legislative bodies met this week to iron out their differences; in the absence of significant opposition the university tax credits survived into the final bill.

David Dickson 